\title{
Social Support and its Relationship to the Life Satisfaction of Breast Cancer Patients
}

Mohamed Hassan Mohamed Ebid (PhD)

Assistant professor Casework

Faculty of Social Work, Aswan University

Hamdy Essayed Ali Ali Assy (PhD)

Assistant professor Social group work

Faculty of social work, Aswan University 



\section{Abstract:}

This study aims to identify the differences in the mean scores on the measures of social support and life satisfaction scale according to the variables of (age, education, stage of therapy, and the period affected). The study sample consisted of (200) breast cancer patients. Their ages ranged from (22-60 years old) with an average age of (43.6) and a standard deviation of (1.8). The study findings indicate that there are no significant statistical differences with the variance of (age, qualification and stage of therapy) variables whereas there are significant statistical differences with the variance of the affected period for breast cancer patients on the dimensions of the social support scale. Moreover, the study findings indicate the level of social support according to variables and that there are significant statistical differences in the level of social support according to variables of education and the length of period affected on the dimensions of the social support scale.

The study findings indicate that there is a significant statistical relationship between social support and life satisfaction. In addition, the study findings indicate that social support has the capability of predicting life satisfaction within the study sample.

\section{Key Words: social support, life satisfaction. Breast Cancer}

\section{Introduction}

Cancer is one of the diseases which are considered a danger to human life mainly because it can affect any organ of the body. Cancer causes a deficiency in the structure of cells which start to reproduce abnormally. These infected cells generate more cells, similar in structure, which finally form a tissue called cancer tumors (Radwan, 2007, p.111).

Breast cancer is classified as one of the most significantly dangerous cancers affecting women in both developed and developing countries. According to statistics of the Egyptian Ministry of Health, the percentage of women affected by breast cancer is (34\%). In addition, breast cancer is the most widespread type of tumor to affect women in Egypt (The Egyptian Ministry of Health, 2018). Breast cancer could be defined as a malignant cancer which causes abnormal growth of breast cells. This kind of tumor usually appears in the milk glands of the breast, but it can also extend to the surrounding breast tissues or to any other organ in the woman's body (American Cancer Society, 2014).

In addition to this, breast cancer can cause a state of anxiety, worry and distress which makes its patient less stable psychologically. A patient with breast cancer may suffer a state of psychological disorder due to the progressive long-lasting concern over the disease and its 
expected outcome. Furthermore, this disease negatively affects women in making and maintaining social relationships due to the affected woman's feelings of shyness and embarrassment as a result of removal of one or both of the breasts. It is also possible for patients with breast cancer to suffer from some social problems causing an inability to face and escape from the pity of others, which can, in turn, cause feelings of social isolation and loneliness (Kleponis, 2006). The results of the study of (Novin et al, 2014), which was applied to (150) women with cancer, indicated that (40) women with cancer suffered from anxiety and depression, and that women with breast and stomach cancer are the most likely to suffer with anxiety and depression respectively. In addition, the findings of the study of (Hassan MR, Shah, et al., 2015) which studied (205) breast cancer patients, indicated that $(31.7 \%)$ of the sample suffered from anxiety, and that (22\%) of the study sample suffered from depression.

Moreover, the relationship between the mind and body of the affected woman becomes disordered which negatively affects the patient's feelings of sexual desire, compounded by a fear of infertility, the negative impact on the patient's body, and the distortion of feelings of sexual attraction (Collins,. Schootman,. Yan., Dean,. Eilers,. \& Jeffe, 2011). In addition, concerning sexual satisfaction of breast cancer patients, (Panjari \& Davis, 2011) performed a study on a sample consisting of (684) women. This study's findings indicated that $(70 \%)$ of participants expressed having sexual problems.

Social support is a very significant and important source of help needed by any individual in his/her daily life, as maintaining good social relationships helps an individual to assess what challenges him/her, such as psychological constraints, enabling them to face such challenges successfully. The amount of social support received affects the way a person recognizes the various challenging constraints, it also affects the ways they might deal with such constraints. In addition, the amount of social support received plays a significant role in decreasing the level of psychological suffering resulting from such constraints (Ali, 2005, p.67).

Receiving social support from others contributes to increasing the quality of life for cancer patients. There are several studies which have tackled the subject of social support for cancer patients and its relation to their life satisfaction. The study of (Kasparian et al, 2009; Knobf, 2011) indicated that the social support received by cancer patients has a positive influence on their lives. This includes increasing the level of their adaptation and adjustment to living with cancer. 
In addition, the study of (Trevino et al, 2013) indicated that there is a positive correlative relationship between social support received by cancer patients and the quality of life they enjoy. The findings of the study of (You \& Lu, 2014) indicated that the family is considered one of the most important sources of social support for Chinese people who recovered from the disease. The findings also indicated that the family support received also increased their quality of life.

The findings of the study of (Salina et al, 2016) indicated a positive correlative relationship between social support and the quality of life for breast cancer patients in Malaysia. The social work profession deals with the human being at various stages of life in order to help him face his problems and reach his full potential for the best possible functioning of his social roles. The study of (Rostman \& Michael, 2009) indicated the effectiveness of therapeutic strategies and approaches related to the elements of the life model in supporting the personal development of people with AIDS, as well as the effectiveness of these methods in lessening the effects of depression and enhancing the network of social relationships for people with AIDS.

In addition, the study of Mabrouk, (2011) indicated the effectiveness of the life model in lessening the acuteness of suffering for women with psychological depression, and enhancing the network of family relationships through the life model using education, elucidation, manipulating the available environmental capabilities, emphasizing both the present and the future, cognitive reconstruction, and home assignments.

Based on the above-mentioned studies, the current study attempts to investigate social support and its relationship to life satisfaction for breast cancer patients.

\section{Importance}

1. A woman could be a daughter, a wife or a mother, or she could often be all of the above, having influence on the whole family.

2. Breast cancer is one of the challenges which face women. Knowing that a woman is suffering from this disease makes her a potential case of progressive ongoing psychological disorder due to constant concern over having the disease and its possible outcome.

3. This research could contribute to developing social support for women with cancer, through their families and social relationships, by giving them a clear reflection of social support's relationship to life satisfaction. This, consequently, would lessen the acuteness of psychological problems breast cancer patients suffer. 


\section{Goals}

1. Studying differences in the degree of social support for breast cancer patients according to variables of age, education, stage of therapy and period affected.

2. Studying differences in the degree of life satisfaction for breast cancer patients according to variables of age, education, stage of therapy and period affected.

3. Indicating and investigating the relationship between social support and life satisfaction for breast cancer patients.

4. Indicating and investigating the expected level of life satisfaction through social support for breast cancer patients.

\section{Concepts}

\section{Social support}

Social support is a person's perception of important social relationships in his/her life which enable him/her to surpass challenges, pressures and problems (Mohamed, Alsadat, Yim \& Chinna, 2015).

Social support represents the help a person receives from others in its various forms and patterns. This support contributes to lessening feelings of sickness and helps to enhance performance leading to increased feelings of happiness and welfare. Receiving or providing social support is significantly correlative with physical hygiene and positive psychological wellbeing (Al-Rawad and Bedair, 2017, p.23). Social support could be defined procedurally as what a breast cancer patient perceives of care, interest, love, advice and information from people in her family or wider social circle. This is estimated through the sum degree a breast cancer patient has on the scale of social support.

\section{Life satisfaction}

Life satisfaction is a psychological feature formed through an individual's perception of the quality of life in which they live in light of their feelings, emotions, attitudes and ability to deal with their surrounding environment. This also includes what a person perceives of protection, satisfaction of needs, contentment and feelings of self-worth, appreciation and acknowledgment (Shaaban, 2013, p.72). In addition, life satisfaction is an individual's personal opinion of their life and his/her estimation and appreciation of it. A person's estimation and appreciation of life is shown through several elements; the most important of which includes their general estimation of life, and assessment of certain topics such as marriage, work, social life, level of happiness, concern, etc... (Soliaman, 2003, p.12).

Life satisfaction is defined procedurally as the state of contentment and satisfaction of a woman, affected by breast cancer, in 
several fields of life. This will be estimated through the Sum degree which an affected woman has on the scale of life satisfaction including psychological satisfaction, satisfaction of the state of health, sexual satisfaction, faith, satisfaction with external appearance, and satisfaction with the possibility of a cure and the medical services provided.

\section{Hypotheses:}

1. There are no significant statistical differences between mean square of the degrees of women with cancer breast on the dimensions of social support scale in light of the variables of (age, education, stage of therapy, and period affected).

2. There are no significant statistical differences between mean square of the degrees of women with cancer breast on the dimensions of life satisfaction scale in light of the variables of (age, education, stage of therapy, and period affected).

3. There is a positive correlative relationship between degrees of breast cancer patients in dimensions of the social support scale and dimensions of the life satisfaction scale.

4. Life satisfaction (the sum degree) can be predicted from social support (the sum degree) for women with breast cancer.

\section{Design of the Study}

This study is based on the descriptive methodology which is suitable for the objectives and hypotheses of the study.

\section{Population}

The study Population consisted of all breast cancer patients (200) who received therapy, surgical, Chemical, Hormone and Radiological at the in the national institute of Tumours in Qena Governorate, and that they are married and have children and marriage life continues.

Tools

\section{1) social support Scale for breast Cancer Patients (Designed by the researchers)}

Prepared by using the study (Kasparian et al, 2009), and study (Knobf, 2011) and study (Salina et al, 2016) and the terms of the scale is formulated in the light of the procedural definition of life satisfaction variable in breast cancer patients, the terms reached (49) as a preliminary image of the scale distributed over the following dimensions: Psychological Satisfaction, Satisfaction about hygiene life, Sexual Satisfaction, Religiousness Satisfaction, Satisfaction with External Appearance, Satisfaction about remedy and medical services. The Scale was presented to a number of professors specialized in social work and psychology. The scale was applied to the surveying sample (60)Patient . Each of the terms of the scale is matched by three responses 
corresponding to grades 1,2 and 3, where grade 3 indicates the lowest level of social support, and grade 1 indicates the highest level of satisfaction with life for the purpose of honesty and consistency of the scale. This was as follows:

\section{Validity}

\section{A- Content Validity}

The preliminary version of the scale was presented to 10 members of the faculty specialized in social work at Helwan University and Aswan University in order to verify the content validity of the scale. In light of the arbitrators' review, the number of the scale statements reached(33).

\section{B-Internal consistency}

Table (1) indicating internal validity using internal consistency between elements of life satisfaction

\begin{tabular}{|c|c|c|c|c|c|c|c|}
\hline $\begin{array}{r}\text { Eleme } \\
\text { nts }\end{array}$ & $\begin{array}{c}\text { Correlat } \\
\text { ion } \\
\text { coeffici } \\
\text { ent }\end{array}$ & $\begin{array}{c}\text { Eleme } \\
\text { nts }\end{array}$ & $\begin{array}{c}\text { Correlat } \\
\text { ion } \\
\text { coeffici } \\
\text { ent }\end{array}$ & $\begin{array}{c}\text { Eleme } \\
\text { nts }\end{array}$ & $\begin{array}{c}\text { Correlat } \\
\text { ion } \\
\text { coeffici } \\
\text { ent }\end{array}$ & $\begin{array}{c}\text { Eleme } \\
\text { nts }\end{array}$ & $\begin{array}{c}\text { Correlat } \\
\text { ion } \\
\text { coeffici } \\
\text { ent }\end{array}$ \\
\hline $1-1$ & $0.571^{* *}$ & $1-11$ & $0.471^{* *}$ & $2-8$ & $0.738^{* *}$ & $3-6$ & $0.584^{* *}$ \\
\hline $1-2$ & $0.640^{* *}$ & $1-12$ & $0.547^{* *}$ & $2-9$ & $0.700^{* *}$ & $3-7$ & $0.548^{* *}$ \\
\hline $1-3$ & $0.525^{* *}$ & $2-1$ & $0.478^{* *}$ & $2-10$ & $0.545^{* *}$ & $3-8$ & $0.582^{* *}$ \\
\hline $1-4$ & $0.779^{* *}$ & $2-2$ & $0.613^{* *}$ & $2-11$ & $0.332^{* *}$ & $3-9$ & $0.541^{* *}$ \\
\hline $1-5$ & $0.865^{* *}$ & $2-3$ & $0.519^{* *}$ & $3-1$ & $0.602^{* *}$ & $3-10$ & $0.548^{* *}$ \\
\hline $1-6$ & $0.532^{* *}$ & $2-4$ & $0.512^{* *}$ & $3-2$ & $0.889^{* *}$ & $3-11$ & $0.510^{* *}$ \\
\hline $1-7$ & $0.511^{* *}$ & $2-5$ & $0.556^{* *}$ & $3-3$ & $0.600^{* *}$ & & \\
\hline $1-8$ & $0.586^{* *}$ & $2-6$ & $0.574^{* *}$ & $3-4$ & $0.79^{* *}$ & & \\
\hline $1-9$ & $0.616^{* *}$ & $2-7$ & $0.448^{* *}$ & $3-5$ & $0.693^{* *}$ & & \\
\hline
\end{tabular}

** Significant elements at level (0.01) * significant elements at level (0.05)

According to table (1), the correlation coefficients between the phrases and dimensions of the scale are all significant at a level of (0.01) indicating that there is high internal validity between phrases and dimensions of the scale. Therefore, the scale has a high degree of validity.

Concerning the level of internal consistency between the main dimensions and total measurement, the researcher reached the following findings indicated in the table below:

Table (2) indicating validity using internal consistency Between dimensions of the social support scale

\begin{tabular}{|c|c|}
\hline Dimensions & Correlation coefficient \\
\hline $\begin{array}{c}\text { Social support from the } \\
\text { family }\end{array}$ & $0.896^{* *}$ \\
\hline $\begin{array}{c}\text { Social support from the } \\
\text { friends }\end{array}$ & $0.543^{* *}$ \\
\hline $\begin{array}{c}\text { Social support from the } \\
\text { others }\end{array}$ & $0.858^{* *}$ \\
\hline
\end{tabular}


According to table (2), the correlation coefficients between the main dimensions and total measurement are all significant at a level of (0.01) indicating that there is high internal validity between the main dimensions and total measurement. Therefore, the scale has a high degree of validity.

\section{Reliability}

\section{A- Cronbach's alpha}

The reliability coefficient of the scale was measured and calculated using the Statistical Package of Social Sciences software (SPSS). A reliability coefficient of $(0.881)$ was indicated which is an indication that this scale has a high degree of reliability.

\section{B- Split Half partition for testing reliability:}

The reliability coefficient of the scale was measured and calculated using the Split Half partition method in the form of Spearman Brown's equation on a sample consisting of (60) women with cancer. A reliability coefficient of (0.797) was indicated which is an indication that this coefficient is a statistically significant correlation coefficient.

\section{2) life satisfaction Scale for breast Cancer Patients (Designed by} the researchers):

Prepared by using the study (Kasparian et al, 2009), and study (Knobf, 2011) and study (Salina et al, 2016) and the terms of the scale is formulated in the light of the procedural definition of life satisfaction variable in breast cancer patients, the terms reached (49) As a preliminary image of the scale distributed over the following dimensions: Psychological Satisfaction, Satisfaction about hygiene life, Sexual Satisfaction, Religiou Satisfaction, Satisfaction with External Appearance, Satisfaction about remedy and medical services. The Scale was presented to a number of professors specialized in social work and psychology. The scale was applied to the surveying sample (60)Patient .Each of the terms of the scale is matched by three responses corresponding to grades 1, 2 and 3, where grade 3 indicates the lowest level of social support, and grade 1 indicates the highest level of satisfaction with life for the purpose of honesty and consistency of the scale. This was as follows:

\section{Validity}

\section{A- Content Validity:}

The preliminary version of the scale was presented to 10 members of the faculty specialized in social work at Helwan University and Aswan University in order to verify the content validity of the scale. 
In light of the arbitrators' review, the number of the scale statements reached(42)

\section{B- Internal consistency:}

Table (3) indicating internal consistency Between elements of life satisfaction scale

\begin{tabular}{|c|c|c|c|c|c|c|c|}
\hline $\begin{array}{c}\text { Eleme } \\
\text { nts }\end{array}$ & $\begin{array}{c}\text { Correlat } \\
\text { ion } \\
\text { coeffici } \\
\text { e.nt }\end{array}$ & $\begin{array}{c}\text { Eleme } \\
\text { nts }\end{array}$ & $\begin{array}{c}\text { Correlat } \\
\text { ion } \\
\text { coeffici } \\
\text { ent }\end{array}$ & $\begin{array}{c}\text { Eleme } \\
\text { nts }\end{array}$ & $\begin{array}{c}\text { Correlat } \\
\text { ion } \\
\text { coeffici } \\
\text { ent }\end{array}$ & $\begin{array}{c}\text { Eleme } \\
\text { nts }\end{array}$ & $\begin{array}{c}\text { Correlat } \\
\text { ion } \\
\text { coeffici } \\
\text { ent }\end{array}$ \\
\hline $1-1$ & $6-1 * *$ & $2-5$ & $0.545^{* *}$ & $4-2$ & $0.463^{* *}$ & $5-6$ & $0.671^{* *}$ \\
\hline $1-2$ & $0.874^{* *}$ & $2-6$ & $0.545^{* *}$ & $4-3$ & $0.698^{* *}$ & $5-7$ & $0.662^{* *}$ \\
\hline $1-3$ & $0.814^{* *}$ & $2-7$ & $0.437^{* *}$ & $4-4$ & $0.720^{* *}$ & $6-1$ & $0.443^{* *}$ \\
\hline $1-4$ & $0.749^{* *}$ & $3-1$ & $0.394^{* *}$ & $4-5$ & $0.365^{* *}$ & $6-2$ & $0.385^{* *}$ \\
\hline $1-5$ & $0.865^{* *}$ & $3-2$ & $0.569^{* *}$ & $4-6$ & $0.500^{* *}$ & $6-3$ & $0.424^{* *}$ \\
\hline $1-6$ & $0.851^{* *}$ & $3-3$ & $0.379^{* *}$ & $4-7$ & $0.478^{* *}$ & $6-4$ & $0.400^{* *}$ \\
\hline $1-7$ & $0.766^{* *}$ & $3-4$ & $0.562^{* *}$ & $5-1$ & $0.655^{* *}$ & $6-5$ & $0.570^{* *}$ \\
\hline $2-1$ & $0.581^{* *}$ & $3-5$ & $0.544^{* *}$ & $5-2$ & $0.437^{* *}$ & $6-6$ & $0.328^{*}$ \\
\hline $2-2$ & $0.751^{* *}$ & $3-6$ & $0.453^{* *}$ & $5-3$ & $0.753^{* *}$ & $6-7$ & $0.683^{* *}$ \\
\hline $2-3$ & $0.618^{* *}$ & $3-7$ & $0.304^{*}$ & $5-4$ & $0.698^{* *}$ & & \\
\hline $2-4$ & $0.693^{* *}$ & $4-1$ & $0.609^{* *}$ & $5-5$ & $0.470^{* *}$ & \\
\hline
\end{tabular}

According to table(3) the correlation coefficients between the phrases are all significant as there are (40) elements which are significant at a level of (0.01) and (2) elements which are significant at a level of (90.05) indicating that there is high internal validity between phrases of the scale. Therefore, the scale has a high degree of validity.

Concerning the level of internal consistency between the main dimensions and total measurement, the researcher reached the following findings indicated in the table below:

Table (4) indicating validity using internal consistency Between dimensions of life satisfaction scale:

\begin{tabular}{|c|c|c|c|}
\hline Dimensions & $\begin{array}{c}\text { Correlation } \\
\text { Coefficient }\end{array}$ & Dimensions & $\begin{array}{c}\text { Correlation } \\
\text { Coefficient }\end{array}$ \\
\hline $\begin{array}{c}\text { psychological } \\
\text { satisfaction }\end{array}$ & $0.725^{* *}$ & $\begin{array}{c}\text { Religiousness } \\
\text { Satisfaction }\end{array}$ & $0.509 * *$ \\
\hline $\begin{array}{c}\text { Satisfaction about } \\
\text { hygiene life }\end{array}$ & $0.358^{* *}$ & External appearance & $0.461^{* *}$ \\
\hline sexual satisfaction & $0.669 * *$ & $\begin{array}{c}\text { Satisfaction about } \\
\text { remedy and medical } \\
\text { services }\end{array}$ & $0.421 * *$ \\
$* *$ Significant dimensions at level $(0.01) *$ significant dimensions at level $(0.05)$
\end{tabular}

According to table(4) the correlation coefficients Between the main dimensions of life satisfaction scale and sum of the measure are all significant at a level of (0.01) which indicates the existence of a high internal consistency Between the main dimensions of the life 
satisfaction scale and their total measure. Consequently, this scale has a high degree of validity.

\section{Reliability}

\section{A- Cronbach's alpha}

The reliability coefficient of the scale was measured and calculated using the Statistical Package of Social Sciences software (SPSS). A reliability coefficient of (0.761) was indicated which is an indication that this scale has a high degree of reliability.

\section{B- The Split Half partition for testing reliability:}

The reliability coefficient of the scale was measured and calculated using the Split Half partition method in the form of Spearman Brown's equation on a sample consisting of (60) women with cancer. A reliability coefficient of $(0.585)$ was indicated which is an indication that this coefficient is a statistically significant correlation coefficient.

\section{Results:}

Result of the first hypothesis:

The first hypothesis of the research states that "There are no significant statistical differences between mean square of the degrees of women with cancer breast on the dimensions of social support scale in light of the variables of (age, education, stage of therapy, and period affected)." The following table indicates the answer to this question:

Table (5) indicating significance of differences in social support

according to variables of age, qualification, stage of therapy and period affected

\begin{tabular}{|c|c|c|c|c|c|c|}
\hline & Source & $\begin{array}{c}\text { Number of } \\
\text { squares }\end{array}$ & DF & $\begin{array}{l}\text { Mean } \\
\text { squares }\end{array}$ & $F$ value & significance \\
\hline \multirow{3}{*}{ Age } & $\begin{array}{c}\text { Between } \\
\text { group } \\
\mathrm{s}\end{array}$ & 59.973 & 3 & 19.991 & \multirow{3}{*}{1.856} & \multirow{3}{*}{$\begin{array}{l}\text { Not } \\
\text { significan } \\
\mathrm{t}\end{array}$} \\
\hline & $\begin{array}{c}\text { Within } \\
\text { group } \\
\text { s }\end{array}$ & $\begin{array}{c}2110.90 \\
2\end{array}$ & 196 & 10.770 & & \\
\hline & Total & $\begin{array}{c}2170.87 \\
5\end{array}$ & 199 & & & \\
\hline \multirow{3}{*}{$\begin{array}{c}\text { Qualificatio } \\
n\end{array}$} & $\begin{array}{c}\text { Between } \\
\text { group } \\
\mathrm{s}\end{array}$ & 0.845 & 2 & 0.845 & \multirow{3}{*}{0.072} & \multirow{3}{*}{$\begin{array}{l}\text { Not } \\
\text { significan } \\
\mathrm{t}\end{array}$} \\
\hline & $\begin{array}{c}\text { Within } \\
\text { group } \\
\text { s }\end{array}$ & $\begin{array}{c}2318.35 \\
0\end{array}$ & 197 & 11.709 & & \\
\hline & Total & $\begin{array}{c}2319.19 \\
5\end{array}$ & 199 & & & \\
\hline $\begin{array}{l}\text { Stage of } \\
\text { therapy }\end{array}$ & $\begin{array}{c}\text { Between } \\
\text { group } \\
\mathrm{s}\end{array}$ & 76.562 & 3 & 15.312 & 1.325 & $\begin{array}{c}\text { Not } \\
\text { significan } \\
\mathrm{t}\end{array}$ \\
\hline
\end{tabular}




\begin{tabular}{|c|c|c|c|c|c|c|}
\hline & $\begin{array}{c}\text { Within } \\
\text { group } \\
\mathrm{s}\end{array}$ & $\begin{array}{c}2242.63 \\
3\end{array}$ & 196 & 11.560 & & \\
\hline & Total & $\begin{array}{c}2319.19 \\
5\end{array}$ & 199 & & & \\
\hline \multirow{3}{*}{$\begin{array}{l}\text { Period } \\
\text { affected }\end{array}$} & $\begin{array}{c}\text { Between } \\
\text { group } \\
\text { s }\end{array}$ & $\begin{array}{c}2819.21 \\
2\end{array}$ & 2 & $\begin{array}{c}1409.6 . \\
6\end{array}$ & \multirow{3}{*}{50.815} & \multirow{3}{*}{$\begin{array}{c}0.000 \\
\text { Significant at } \\
\text { level } \\
(0.01)\end{array}$} \\
\hline & $\begin{array}{c}\text { Within } \\
\text { group } \\
\text { s }\end{array}$ & $\begin{array}{c}5464.78 \\
8\end{array}$ & 197 & 27.740 & & \\
\hline & Total & $\begin{array}{c}8284.00 \\
0\end{array}$ & 199 & & & \\
\hline
\end{tabular}

According to table (5) there are no significant statistical differences with the variance of age, qualification, stage of therapy for breast cancer patients in dimensions of social support whereas there are significant statistical differences with the variance of the period affected. In addition, the following table indicates the nature and direction of differences between groups according to variance in length of the affected period .

Table (6) indicating results of (LSD) Test for determining and

identifying direction of the differences between groups:

\begin{tabular}{|c|c|c|c|}
\hline Period affected & $\begin{array}{r}\text { A year or } \\
\text { (less) }\end{array}$ & $\begin{array}{c}\text { (1 year }-3 \\
\text { years })\end{array}$ & $\begin{array}{r}3 \text { years or } \\
\text { more }\end{array}$ \\
\hline A year or (less) & & & \\
\hline $\begin{array}{c}\text { (1 year }-3 \\
\text { years) }\end{array}$ & $4.968^{*}$ & & \\
\hline 3 years or more & $12.240^{*}$ & $17.208^{*}$ & \\
\hline
\end{tabular}

According to table (6), there are statistically significant differences between the period affected (1 year or less) and the period ( $1-3$ years) for the sake of the latter, whereas the differences are not significant in the period (1 year or less) compared with the period (3 years or more) in the direction of the period (1 year or less). In addition, there are significant differences in the period (1 year -3 years) compared with the period ( 3 years or more) for the sake of the group (1 year -3 years).

\section{Result of the second hypothesis:}

The second hypothesis proposes that "there are no statistically significant differences in mean square of degrees of breast cancer patients in the dimensions of the life satisfaction scale in light of (age, education, stage of therapy and period affected) variables". The following table indicates the answer to this question: 
Table (7) indicating significance of differences in life satisfaction according to variables of age, qualification, stage of therapy and period affected

\begin{tabular}{|c|c|c|c|c|c|c|}
\hline & Source & $\begin{array}{l}\text { Number of } \\
\text { squares }\end{array}$ & DF & $\begin{array}{c}\text { Mean } \\
\text { squares }\end{array}$ & $\begin{array}{c}\mathrm{F} \\
\text { value }\end{array}$ & significance \\
\hline \multirow{3}{*}{ Age } & $\begin{array}{l}\text { Between } \\
\text { groups }\end{array}$ & 2825.510 & 3 & 941.837 & \multirow{3}{*}{31.093} & \multirow{3}{*}{$\begin{array}{c}0.000 \\
\text { Significant at } \\
\text { level } \\
(0.01)\end{array}$} \\
\hline & $\begin{array}{l}\text { Within } \\
\text { groups }\end{array}$ & 5937.085 & 196 & 30.291 & & \\
\hline & Total & 8762.595 & 199 & & & \\
\hline \multirow{3}{*}{ Qualification } & $\begin{array}{l}\text { Between } \\
\text { groups }\end{array}$ & 206.850 & 2 & 103.425 & \multirow{3}{*}{2.381} & \multirow{3}{*}{$\begin{array}{c}0.095 \\
\text { Not significant }\end{array}$} \\
\hline & $\begin{array}{l}\text { Within } \\
\text { groups }\end{array}$ & 8555.745 & 197 & 43.430 & & \\
\hline & Total & 8762.595 & 199 & & & \\
\hline \multirow{3}{*}{$\begin{array}{l}\text { Stage of } \\
\text { therapy }\end{array}$} & $\begin{array}{l}\text { Betwee } \\
\text { n } \\
\text { groups }\end{array}$ & 720.635 & 3 & 240.212 & \multirow{3}{*}{5.854} & \multirow{3}{*}{$\begin{array}{c}0.001 \\
\text { Significant at } \\
\text { level } \\
(0.01)\end{array}$} \\
\hline & $\begin{array}{l}\text { Within } \\
\text { groups }\end{array}$ & 8041.960 & 196 & 41.030 & & \\
\hline & Total & 8762.595 & 199 & & & \\
\hline \multirow{3}{*}{$\begin{array}{l}\text { Period of } \\
\text { affected }\end{array}$} & $\begin{array}{c}\text { Betwee } \\
n \\
\text { groups }\end{array}$ & 139.121 & 2 & 69.560 & \multirow{3}{*}{1.589} & \multirow{3}{*}{$\begin{array}{c}2.207 \\
\text { Not significant }\end{array}$} \\
\hline & $\begin{array}{l}\text { Within } \\
\text { groups }\end{array}$ & 8623.474 & 197 & 43.774 & & \\
\hline & Total & 8762.595 & 199 & & & \\
\hline
\end{tabular}

According to table(7)there are significant statistical differences with the variances of age and stage of therapy for breast cancer patients in the dimensions of life satisfaction, whereas there are no significant statistical differences with the variances of qualification and period affected. In addition, the following table indicates the nature and direction of differences between groups according to ages:

Table (8) indicating results of (LSD) Test for determining and identifying direction of differences between groups:

\begin{tabular}{|c|c|c|c|c|}
\hline Age & $\begin{array}{c}(20- \\
30)\end{array}$ & $(31-40)$ & $(41-50)$ & $(51-60)$ \\
\hline$(20-30)$ & & & & \\
\hline$(31-40)$ & $8.779^{*}$ & & & \\
\hline$(41-50)$ & $9.130^{*}$ & $0.353^{*}$ & & \\
\hline$(51-60)$ & 2.515 & $6.263^{*}$ & $6.615^{*}$ & \\
\hline Therapy & Surgical & Chemical & Radiological & Hormone \\
\hline Surgical & & & & \\
\hline Chemical & $10.679^{*}$ & & & \\
\hline Radiological & $7.294^{*}$ & $3.385^{*}$ & & \\
\hline
\end{tabular}




\section{\begin{tabular}{|c|c|c|c|}
\hline Hormone & $8.895 *$ & $1.785^{*}$ & $1.601 *$ \\
\hline
\end{tabular}}

As indicated through table (8), the differences are between the ages ranging from $(20-30$ years old $)$ compared with groups aged between $(31-40$ years old, $41-50$ years old). The differences are in the direction of the groups aged between $(20-30$ years old $)$ whereas the differences in the group aged $(51-60$ years old) are compared to the groups aged ( $31-40$ years old and $41-50$ years old). Moreover, the differences are in the direction of the group aged (50 - 60 years old).

Moreover, as indicated through table (8), there are differences with the variance of therapy nature as the differences are in the direction of surgical therapy compared to other types of therapy including (chemical, radiological and hormone therapy). In addition, there are differences in both the chemical therapy and the radiological therapy for the sake of the radiological therapy group.

\section{Result of the third hypothesis:}

The third hypothesis proposes that "There is a positive correlative relationship between degrees of breast cancer patients in dimensions of the social support scale and dimensions of the life satisfaction scale".

Table(9) indicating the correlative relationship between social support and life satisfaction for breast cancer patients:

\begin{tabular}{|c|c|c|c|c|c|c|c|}
\hline $\begin{array}{c}\text { Sum } \\
\text { of } \\
\text { scale }\end{array}$ & Therapy & Appearance & Faith & $\operatorname{sex}$ & $\begin{array}{l}\text { Hard } \\
\text { life }\end{array}$ & life & $\begin{array}{l}\text { Satisfaction } \\
\text { about support }\end{array}$ \\
\hline $0.31 * *$ & 0.13 & 0.05 & $0.21 * *$ & $0.42 * *$ & -0.08 & $0.16^{*}$ & $\begin{array}{l}\text { support of } \\
\text { family }\end{array}$ \\
\hline 0.063 & 0.069 & $0.224 * *$ & $\begin{array}{c}- \\
0.211 * *\end{array}$ & $0.06^{-}$ & $-0.17 *$ & $0.28 * *$ & $\begin{array}{l}\text { support of } \\
\text { friends }\end{array}$ \\
\hline-0.01 & $0.41 * *$ & -0.08 & 0.01 & 0.10 & 0.54 & $\begin{array}{c}- \\
0.20 * * \\
\end{array}$ & $\begin{array}{c}\text { Support of } \\
\text { others }\end{array}$ \\
\hline $0.18 * *$ & $0.25 * *$ & 0.117 & -0.004 & $0.22 * *$ & -0.119 & $0.16^{*}$ & Sum of scale \\
\hline
\end{tabular}

As indicated through table (9), there is a positive correlative relationship with statistical significance at a level of (0.01) between social support and life satisfaction for breast cancer patients.

\section{Result of the fourth hypothesis:}

The fourth hypothesis proposes that "Life satisfaction (the sum degree) can be predicted from social support (the sum degree) for women with breast cancer". The following table indicates the results of statistical processing:

Table (10) indicating results of the simple deviation analysis of the predicting independent variable: (social support), and the dependent expected variable(life satisfaction) for breast cancer patients (number $=200$ ): 


\begin{tabular}{|c|c|c|c|c|c|c|c|c|}
\hline $\begin{array}{c}\text { Depende } \\
\text { nt } \\
\text { variable }\end{array}$ & $\begin{array}{c}\text { Independ } \\
\text { ent } \\
\text { variable } \\
\text { (Predictin } \\
\text { g) }\end{array}$ & $\begin{array}{c}\text { Multipl } \\
\text { e } \\
\text { correlati } \\
\text { on } \\
\text { coeffici } \\
\text { ent } \\
\text { (R) }\end{array}$ & $\begin{array}{c}\text { Square } \\
\text { of } \\
\text { multiple } \\
\text { correlati } \\
\text { on } \\
\text { coefficie } \\
\text { nt }\end{array}$ & $\begin{array}{c}\text { Valu } \\
\text { e (F) }\end{array}$ & $\begin{array}{c}\text { Deviatio } \\
\mathrm{n} \\
\text { coefficie } \\
\text { nt (B) }\end{array}$ & $\begin{array}{c}\text { Value } \\
\text { of } \\
\text { (Beta) }\end{array}$ & (T) & $\begin{array}{c}\text { The } \\
\text { stable } \\
\text { value }\end{array}$ \\
\hline $\begin{array}{c}\text { life } \\
\text { satisfact } \\
\text { ion }\end{array}$ & $\begin{array}{c}\text { social } \\
\text { support }\end{array}$ & 0.189 & 0.036 & $\begin{array}{c}7.35 \\
8 * *\end{array}$ & 0.184 & 0.189 & $2.71 * *$ & 61.367 \\
\hline
\end{tabular}

$* * \rightarrow$ Significance at the level of $(0.01)$

As indicated through table (10), social support has the ability to predict life satisfaction with the study sample as the value of $(\mathrm{F})$ is (7.358) which is a statistically significant value at a level of (0.01). In addition, the value of $(\mathrm{T})$ is (2.713) of the social support variable, this is a statistically significant value at a level of (0.01). As the contribution percentage of social support in predicting life satisfaction is (3.6\%). The deviation mathematical equation could be stated as the following equation indicates: Degree of life satisfaction $=61.367+(0.184 \mathrm{x}$ social support).

\section{Discussion}

This study indicates that there are no statistically significant differences in the level of social support for breast cancer patients according to variables of (age, education and therapy period). This could be interpreted that breast cancer patients need social support regardless of their age, educational level, or the stage of therapy they have reached, as patients usually suffer emotions of fear, worry and anxiety. In addition, a patient with breast cancer is usually in need of people who can support her to overcome the side effects of the disease. This result agrees with the results of the study of (Tashtoush, 2015) which illustrated that "there are statistically significant differences in the level of social support according to variables of (age, education and the stage of therapy)".

This study also indicates that there are statistically significant differences in the level of social support according to the length of the affected period. This could be interpreted as a newly diagnosed patient of breast cancer being in need of more social support in order to comprehend the nature of her disease and accept the effects of the disease. In addition, a newly diagnosed breast cancer patient will need to know how to overcome the disease. Moreover, patients with breast cancer, whose affected periods exceed (3 years or more), understand the fatal potential of this disease, they have experienced various stages of therapy and more importantly, have accepted the outcome this disease may bring. 
Study findings indicate that there are differences in level of life satisfaction for breast cancer patients aged between $(20-30$ years old). This could be interpreted through indicators that this group faces some challenges such as deformity resulting from surgical operations. In addition, the side effects of therapy are more severe with young women than with older women as young women lose one of the most important organs of her femininity. Furthermore, a younger woman's matrimony deteriorates at this stage. This result agrees with the study of (Arraras et al, 2013) which indicated that the level of life satisfaction for breast cancer patients decreases correlatively with age.

The study findings indicate that the level of life satisfaction for breast cancer patients who have had surgery is lower than the level of life satisfaction for breast cancer patients who have not. This is because the side effects of surgery include pain and inflammation in the area of the operation. However, the side effects of chemical and radiological therapy include dermatological burns, hair loss, weight gain and decreased immunity. In addition, the side effects of hormone therapy includes only weight gain. This result agrees with the study of (Han et al, 2010) which indicated that the level of life satisfaction for breast cancer patients who had surgical operations is lower than the level of life satisfaction for breast cancer patients who are subject to other types of therapy.

There are no significant statistical differences in the level of life satisfaction with the variance of qualification which indicates that variance of qualification does not affect significantly on life satisfaction for the study sample. This could be interpreted that breast cancer patients, with their various qualifications, receive social support including feelings of safety, happiness and self-confidence. Therefore, breast cancer patients have a feeling of life satisfaction.

There are no significant statistical differences in the level of life satisfaction with the variance in length of the affected period which indicates that the length of the affected period does not impact significantly on life satisfaction for the study sample. This is because a breast cancer patient adjusts to life with this disease as she comes to terms with the nature of her disease.

There is a positive correlative relationship between social support and life satisfaction for breast cancer patients. This could be interpreted that social support assists in enhancing the individual's performance of various works. In addition, social support contributes to increasing levels of happiness and welfare, as receiving social support from other trusted groups such as a husband, sons, family, relatives or friends, is positively correlated with life satisfaction. This result is 
consistent with the studies of (Niokolice et al, 2015; Ozolat, Ayaz, Konag \& Ozkan, 2014; Tashtoush, 2015) which indicate that social support has a positive influence in decreasing psychological stress as well as enhancing the level of social support for breast cancer patients.

The study findings indicate that social support has the ability to predict life satisfaction for breast cancer patients as social support has a positive effect in decreasing psychological anxiety and enhancing the level of life satisfaction for breast cancer patients. This result agrees with the study of (Svetina \& Nastran, 2012; Rabiea, 2013). Both of these studies have indicated that social support has the ability to predict the level of life satisfaction. In addition, both of these studies have indicated that social support is able to predict life satisfaction and feelings of safety.

\section{References:}

Ali, Abdel Salam. (2005). Social support and practical applications in our daily lives, Cairo: Al-Najlo Library The Egyptian

Al-Rawad, Diab Mohamed, Bedair and Tahany Rizk (2017). Conceived Social Support and its Relation to Psychological Security of Divorced Women, Journal of Educational and Psychological Sciences, The National Center of Researches, Palestine, 1(2), P.130-153.

American Cancer Society. (2014). Breast cancer facts\& figures 20132014. Atlanta: American Cancer Society.

Arraras, J., Illarramendi, J., Viudez, A., Ibáñez, B., Lecumberri, M., de la Cruz, S., Hermandez, B., Zarandona, U., Cambra, K., Collins, K. K, Liu, Y., Schootman, M., Aft, R., Yan, Y., Dean, G. Egyptian Ministry of Health (2018). Annual Statistics of Breast Cancer.

Han, J., Grothuesmann, D., Neises, M., Hille, U. \& Hillemanns, P. (2010). Quality of life and satisfaction after breast cancer operation. Arch Gynecol Obstet, P. 282, 75-82.

Hassan MR, Shah SA, Ghazi HF, Mujar NM, Samsuri MF, Baharom N. (2015). Anxiety and Depression among Breast Cancer Patients in an Urban Setting in Malaysia. Asian Pac j Cancer Prev. journal, 16(9), P. 4031-4035.

Kasparian N.A, Mcloone J.K, Butow P.N. (2009).Psychological responses and coping strategies among Patient with malignant melanoma: a systematic review of the literature. Archdermato, P. 145,1415-1427.

Kleponis, P. (2006). Communication in Marriage. Ret rive march, 2013, from http://www.maritalhealing.com.

Knobf MT. (2011). Clinical update: psychosocial responses in breast cancer survivors SeminOncolNurs. 2011 Aug; 27 (3). 
Mabrouk, Mohamed Shehata (2011). Practicing Model of Life in the individual service to lessen Familial Stresses accompanying Cases of Depression, Journal of Studies in Social Work and Human Sciences, 31(21) October, Faculty of Social Work, Helwan University.

Mohammad, A., Al Sadat, N., Yim, L and Chinna, K. (2015). Validity and Reliability of the Hausa Version of Multidimensional Scale of Perceived Social Support Index. Iran Red Crescent Med J. 17(2), P. 1-7.

Nikolić, S., Ilić-Stošović, D., Kolarević, I., Djurdjević, A., Ilić, S. \& Djurićić. (2015). Social participation of women with breast cancer. Vojnosanitetski Pregled, 72(2), 148-154P.

Novin Nikbakhsh, Sussan Moudi, Setareh Abbasian, and Soraya Khafri (2014). Prevalence of depression and anxiety among cancer patient, Caspian journal of Intern Med, 5(3), 167-170P.

Ozolat, A., Ayaz, T., Konag, O. \& Ozkan, A. (2014). Attachment style and perceived social support as predictors of bio psychosocial adjustment to cancer. Turk J Med Sci, 44 ,P. 24-30

Panjari, M., Bell, R. J. \&, Davis, S. R. (2011). Sexual function after breast cancer. J Sex Med, 8(1), P.294-302.

Rabiea, HebaBahy El-Din (2013). Some Predicting Variables of Life satisfaction with Patient Breast cancer patients, Journal of Psychological Studies, 4(23), 419-457P, Egypt.

Radwan, Samer (2007). Mental Hygiene, El-Maysara House for Printing and Publishing, Amman, Jordan.

Rostman, L. \& Michael, E. (2009). Integrative treatment model, dissertation abstract, south Africa.

Salina. M, Chong. G, Mee. H, Faizah. H, Maznah. D, Ahmed. H, Nor. Z, Nur. H. (2016). Anxiety, depression perceived social support and quality of life in Malaysian breast cancer patient a one- year prospective study, Psych oncology Journal, 25 (1), P.19-27.

Shaaban, Doaa Shaaban (2013). Life satisfaction and its Relation to Future Worrying with Freed prisoners Departed to Gaza Region, Unpublished Master Thesis, Faculty of Education, The Islamic University at Gaza.

Soliaman, Adel Mahmoud (2003). Life satisfaction and its Relation to Self-Estimation for Headmasters and Headmistresses of Governmental Schools, Al-Nagah National University, Palestine.

Svetina, M. \& Nastran, K. (2012). Family relationships and posttraumatic growth in breast cancer patients. Psychiatra Danub, 24(3),P. 298-306. 
Tashtoush, RamyAbd-Allah (2015). Life satisfaction and Conceived Social Support and the Relation between them for breast cancer patients, Jordanian Journal of Educational Sciences, 4(11), 449-467P.

Trevino, K.M., Fasciano, K., Block, S. \& Prigerson, H.G. (2013). Correlates of social support in young adults with advanced cancer. Support Care Cancer, 21, 421-429P. DOI 10.1007/s00520-012-1536-2. World Health Organization (2014). Breast Cancer, Protection from it, How to Fight it, Geneva, Switzerland.

You.J, Lu. Q. (2014).Sources of social support and adjustment among Chinese cancer survivors: gender and age differences. Support Care Cancer,22, 697-704P. DOI 10.1007/s00520-013-2024-z. 